\title{
The Application of the Seaweeds in Neutralizing the "Ocean Acidification" as a Long-Term Multifaceted Challenge
}

\author{
Vincent van Ginneken \\ Blue-Green Technologies, Heelsum, The Netherlands \\ Email: vincent@bluegreentechnologies.nl
}

How to cite this paper: van Ginneken, V. (2019). The Application of the Seaweeds in Neutralizing the "Ocean Acidification" as a Long-Term Multifaceted Challenge. Journal of Geoscience and Environment Protection, 7, 126-138.

https://doi.org/10.4236/gep.2019.712009

Received: June 6, 2019

Accepted: December 16, 2019

Published: December 19, 2019

Copyright () 2019 by author(s) and Scientific Research Publishing Inc. This work is licensed under the Creative Commons Attribution International License (CC BY 4.0).

http://creativecommons.org/licenses/by/4.0/

\begin{abstract}
The global effects of ocean acidification (OA) on coral reefs are of growing concern. Carbon dioxide released into the atmosphere as a result of burning fossil fuels, not only has an effect on "global warming", but also on OA which is called the "other $\mathrm{CO}_{2}$ problem". OA combined with high ocean temperatures has resulted in a massive bleaching of coral reefs in the Indian Ocean and throughout Southeast Asia over the past decade, which is ultimately lethal. Here we discuss the option if innovative seaweed biotechnology-the Ulva lactuca bioreactor option, with its $\mathrm{H}^{+}$ion-absorbing capacity and its huge green biomass production of around $50 \mathrm{MT} / \mathrm{ha} / \mathrm{year}$ - which can stabilize our "World Ocean" and our global coral reefs. From our calculations, we came to the conclusion that an area covered with "Ulva lactuca bioreactors" with a production capacity of $250 \times 10^{16}$ ha of seaweed per year is needed to remove all $\mathrm{H}^{+}$ions that cause $\mathrm{OA}$ in our "World Ocean" since the beginning of the "Industrial Revolution" $\approx 250$ years ago. This is a daunting task and therefore we have opted for a multi-faceted approach including variability in seaweed species, avoidance of eutrophication \& heavy-metal accumulation, prevention of global warming by more green-biomass production and a better estimation of the huge Kelp seaweed populations in temperate zones in order to protect our coral reefs for the short term.
\end{abstract}

\section{Keywords}

Ocean Acidification, Coral Reefs, Bleaching, Seaweed, Ulva lactuca, Ulva-Bioreactor, World Ocean, Seaweed-Based Economy

\section{Introduction}

The worldwide effects of ocean acidification $(\mathrm{OA})$ on coral reefs are of growing 
concern (Doney et al., 2009). Carbon dioxide released into the atmosphere as a result of burning of fossil fuels has not only an effect on "global warming" (Oreskens, 2004). But, also on OA which is called the "other $\mathrm{CO}_{2}$ problem" (Barker \& Ridgwell, 2012). OA in combination with high ocean temperatures resulted the last decade in a massive bleaching of coral reefs in the Indian Ocean and throughout Southeast Asia, which is finally lethal (Normille, 2010). Here we discuss the option if we can via innovative seaweed biotechnology- "the Ulva lactuca bioreactor" option (Figure 1 ) with its $\mathrm{H}^{+}$ion absorbing capacity (van Ginneken, 2017) and its tremendous green biomass production of around 50 MT/ha/year (Bruhn et al., 2011, van Ginneken \& de Vries, 2016)—stabilize our "World Ocean" and protect our coral reefs.

Carbon dioxide $\left(\mathrm{CO}_{2}\right)$ is an important heat-trapping (greenhouse) gas, which is released through human activities such as deforestation and burning fossil fuels, as well as natural processes such as respiration and causes "global warming" (Oreskens, 2004). Around the millennium time-series measurements of atmospheric $\mathrm{O}_{2}$ and $\delta^{13} \mathrm{C}$ showed that the world oceans annually sequestered $2.0 \pm 0.6$ gigatons (GT) of Carbon between mid-1991 and mid-1997 (Battle et al., 2000). Dissolving $\mathrm{CO}_{2}$ in seawater increases the hydrogen ion $\left(\mathrm{H}^{+}\right)$concentration in the ocean, and thus decreases ocean $\mathrm{pH}$, as follows ( $\mathrm{Ra}$ ven et al., 2005):

$$
\mathrm{CO}_{2(\mathrm{aq})}+\mathrm{H}_{2} \mathrm{O} \Leftrightarrow \mathrm{HCO}_{3}^{-}+\mathrm{H}^{+} \Leftrightarrow \mathrm{CO}_{3}^{2-}+2 \mathrm{H}^{+} \text {(see Figure 2). }
$$

Consequently, an ongoing decrease in the $\mathrm{pH}$ of the Earth's oceans took place until the first decade of the $21^{\text {st }}$ century with an estimated oceanic "acidity" to be around 30\% (Hall-Spencer et al., 2008).

So, after the millennium it became clear that the oceans had been during the industrial era acting as a massive sink for anthropogenic $\mathrm{CO}_{2}$ from the atmosphere which is called "the other $\mathrm{CO}_{2}$ problem" (Doney et al., 2009; Barker \& Ridgwell, 2012) or "Ocean Acidification” (OA) (Hall-Spencer et al., 2008; Caldeira \& Wickett, 2003).

Coral reefs and other marine organisms whose skeletons or shells contain calcium carbonate may be particularly affected, as calcification rates of the Australia's Great Barrier Reef over the past twenty years indicated (Pennisi, 2009). OA in combination with high ocean temperatures resulted the last decade in a massive bleaching (disturbance of symbiotic balance between the corals and photosynthetic algae) of Coral reefs in the Indian Ocean and throughout Southeast Asia, which is finally lethal (Normille, 2010).

Caldeira \& Wickett (2003) placed the rate and magnitude of modern OA changes in the context of probable historical changes during the last 300 million years. Since the industrial revolution began, it is estimated that surface ocean $\mathrm{pH}$ has dropped by slightly more than 0.1 units on the logarithmic scale of $\mathrm{pH}$, representing about a $29 \%$ increase in $\mathrm{H}^{+}$(Figure 2 ). It is expected to drop by a further 0.3 to $0.5 \mathrm{pH}$ units (Mora et al., 2013) (an additional doubling to tripling of today's post-industrial acid concentrations). By 2100 as the oceans absorb more anthropogenic $\mathrm{CO}_{2}$, the impacts being most severe for coral reefs and the 


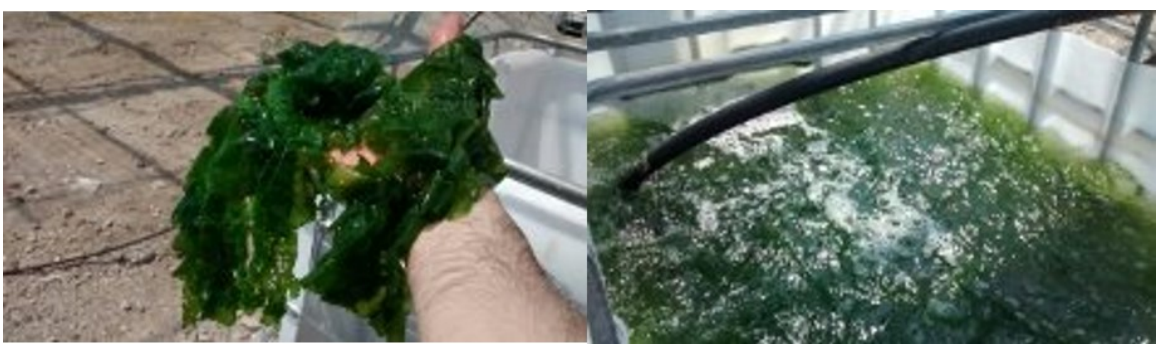

Figure 1. "Ulva lactuca bioreactor" model which gave annual Ulva lactuca biomass production data of around $50 \mathrm{Mt}$ (metric tonnes) dry weight/ha/year $(\approx 365$ days) (Source modified: van Ginneken \& de Vries, 2016).

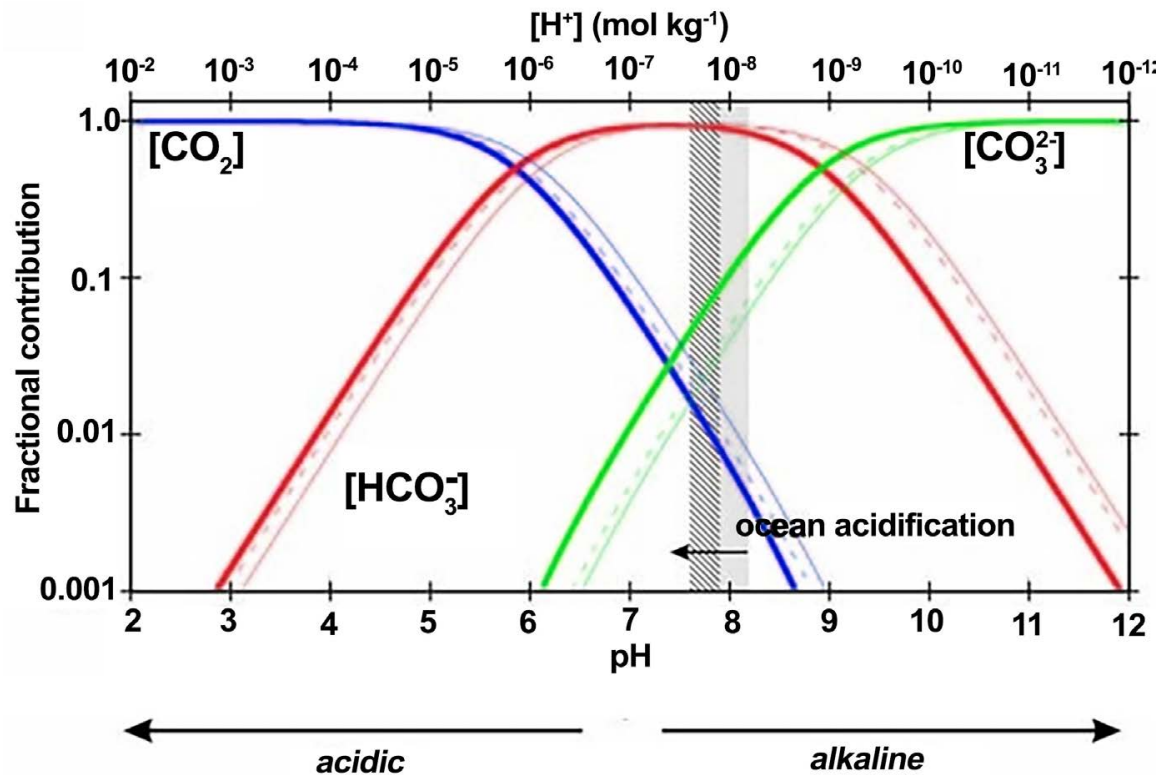

Figure 2. The Biophysical process of Ocean Acidification (OA). In theory Seaweed biomass production is severely hampered by a 10,000-fold slower diffusion rate of a Carbon source or Dissolved Inorganic Carbon (DIC) in the biophysical medium water in comparison to terrestrial C3 crops. Despite this detrimental property pelagic seaweeds outcompetes C3 crops for annual green biomass production which is called "the seaweed-paradox" (van Ginneken, 2017). Here we have reported our findings and hypothesized that for four seaweed species that due to an internal acidification the abundant oceanic bicarbonate ion $\left(\mathrm{HCO}_{3}^{-}\right)$is introduced into the cell which will in the inner acidic mitochondrial environment (matrix) rapidly be converted to $\mathrm{CO}_{2}$ which is the only C-form photosynthetic enzyme ribulose-1,5-bisphosphate carboxylase/oxygenase (Rubisco) can react with to produce with solar energy and water green biomass. We hypothesize this intracellular acidification is performed by reversal of the fifth pump of the chemi-osmotic model of Mitchell (van Ginneken, 2017). It can be expected that in nearby future seaweeds may play a prominent role in providing the unfettered growth of the world population-estimated at around 10 billion people at the midst of the 21 st century: food, fuel and other bioactive ingredients (van Ginneken \& de Vries, 2016; Hurd et al., 2014).

Southern Ocean (Raven et al., 2005; Caldeira \& Wickett, 2003; Orr et al., 2005). These changes are predicted to accelerate as more anthropogenic $\mathrm{CO}_{2}$ is released to the atmosphere and taken up by the oceans. 
In temperate coastal seas, seaweeds are dominant primary producers that create complex habitats and supply energy to higher trophic levels (Hurd et al., 2014). These seaweed communities or seaweed plantations (van Ginneken et al., 2016), can also stabilize the $\mathrm{pH}$ of the seawater, thus preventing a further OA.

We hypothesize that due to the sequestering capacity of $\mathrm{H}^{+}$ions or seaweeds this oceanic crop in theory must be able to prevent ocean acidification (OA) due to $\mathrm{H}^{+}$ions and that this should be theoretically possible for our "World Ocean".

Here we will present-based on the $\mathrm{H}^{+}$ions sequestering ability of seaweeds, which is characteristic for their photosynthetic system (van Ginneken, 2017) our calculations for land-based systems like the seaweed "Ulva lactuca-bioreactor" (Figure 1), with an annual biomass production of $\approx 50$ metric ton/ha/year (Bruhn et al., 2011; van Ginneken \& de Vries, 2016).

\section{Material \& Methods}

\subsection{Experimental Set Up}

The following materials were used in the experiments:

\subsection{Seaweeds}

- Ulva lactuca (Chlorophyta): $\geq$ origin: Katse Heule, Easters-Scheldt, The Netherlands; approximate coordinates: $51^{\circ} 32^{\prime} 30^{\prime \prime} \mathrm{N}$ and $3^{\circ} 52^{\prime} \mathrm{E}$.

- Caulerpa sertularioides (Chlorophyta): $\geq$ origin: Denpassar, Bali, Indonesia; approximate coordinates: $8^{\circ} 41^{\prime} \mathrm{S}$ and $115^{\circ} 1$

- Caulerpa cf. brachypus (Chlorophyta): $\geq$ origin: Cuba): approximate coordinates: $23^{\circ} 50^{\prime} \mathrm{S}$ and $82^{\circ} 50^{\prime} \mathrm{W}$.

- Undaria pinnatifidia, (Wakame) (Phaeocophycea): $\geq$ origin, Kilcar, West-Donegal, Ireland, approximate coordinates: $54^{\circ} 37^{\prime} \mathrm{N}$ and $8^{\circ} 37^{\prime} \mathrm{W}$.

\subsection{Sampling and Purchasing Seaweeds and Identification Procedures}

Ulva lactuca was collected ourselves and brought directly to the laboratorytogether with surrounding water-for species determination with a binocular and microscope. The other three seaweed species (Caulerpa sertulariodes, Caulerpa cf. brachypus, Undaria pinnatifida) were fresh provided by an aquarium wholesaler for seaweed species "De Jong Marinelife", Spijk, (The Netherlands) a purchaser for marine aquariums, with a network of international worldwide contacts. This "aquarium-shop" delivers oceanic sea fishes, corals and seaweeds which are flown together with native surrounding water asp to the shop. Here species were identified by name and with a binocular and microscope.

Earlier (van Ginneken, 2017; van Ginneken, 2018; van Ginneken \& de Vries, 2018) we determined for four seaweed species under mechanical pressure until 10 bar pressed moisture weight out of the seaweed fronds for further biochemical analysis. All investigated four seaweeds species gave moisture and Oceanic water and seaweed moisture were measured for salinity, $\mathrm{pH}$ and by Inductively 
Coupled Plasma Spectroscopy (ICP)-techniques concentrations for macro-elements: (Ca, Fe, K, Mg, Mn, Na, P, \& S), micro-elements $\approx[\mathrm{HM}]:(\mathrm{Al}, \mathrm{As}, \mathrm{Cd}$, $\mathrm{Co}, \mathrm{Cr}, \mathrm{Cu}, \mathrm{Mo}, \mathrm{Ni}, \mathrm{Pb} \& \mathrm{Zn}$ ) and nutrients (N-total \& P-total). With ICP-techniques we investigated it among else for macro- and micro-elements. The [seawater compound $\mathrm{X}] /[$ oceanic compound $\mathrm{X}$ ] ration is a reflection of an inward (uptake) or excretion mechanism over the seaweed cellular membrane which is operative (van Ginneken, 2017; van Ginneken, 2018; van Ginneken \& de Vries, 2018).

\subsection{Mechanical Pressure Procedure}

To be able to press seaweed moisture out of the seaweed biomass the materials were first pulped using a laboratory homogenizer (manufacturer: Foss Tecator, type: Tecator 1094 homogenizer). For seaweed biomass a smooth knife was used, for others a serrated knife was used. For most materials the lower speed of 1500 rpm was sufficient, for other the higher speed of $3000 \mathrm{rpm}$ was needed. Juice was pressed out of the pulp, approximately 100 grams of pulp was used, using a LLOYD INSTRUMENTS (type: LR30K) testing machine that was fitted with a specially constructed unit for pressing pulps at a maximum pressure of 60 bar (Figure 3: Panel 1, 2). Pulps were first pressed for 5 minutes at a pressure of 2 bars, after that for another 5 minutes at a pressure of 10 bars (Figure 3: Panel 3). Applied pressure, thickness of the press cake and cumulative juice production (Figure 3: Panel 4), were continuously monitored. Total weight of press cake and press juice were determined. Afterwards press cake and samples of the obtained seaweed moisture of the four different seaweed species $(n=4$ per seaweed species) were immediately stored at $-80^{\circ} \mathrm{C}$ pending analyses. This procedure was earlier described in (van Ginneken, 2017; van Ginneken, 2018; van Ginneken \& de Vries, 2018).

Theoretical data for our Calculations: Our "World Ocean"-with its tremendous amount of 1.37 billion cubic kilometer of saltwater-has since start of the Industrial Revolution act as a sink by sequestering massively per annum $9 \mathrm{Gt}$ $\mathrm{CO}_{2}$ produced by our fossil driven economic (Raven et al., 2005).

Calculations: Of the $\approx 10,000$ seaweed species in our oceans (Hurd et al., $2014) \approx 98 \%$ of the worlds cultivated seaweed production consist of the following leading five genera Saccharina, Undaria, Porphyra, Eucheuma/Kappaphycus and Gracilaria which cover 3\% of our oceans (Buschmann et al., 2017). So, we allowed us, for these fast-growing pelagic seaweed-species to select two of them, "Sea lettuce" Ulva lactuca and "Asian Kelp" (Undaria pinnatifidia), to make a calculation about the neutralizing capacity of our "World Ocean".

If we calculate based on the present amount of global seaweed production the $\mathrm{H}^{+}$sequestering in seaweed biomass we can further calculate how much more seaweed biomass needs to be produced in our oceans to neutralize our "World Ocean". Recent data indicated seaweeds produce only a small fraction of the global supply of global green biomass below $\approx 30 \times 10^{6}$ fresh weight $(\mathrm{FW})$ ton of 


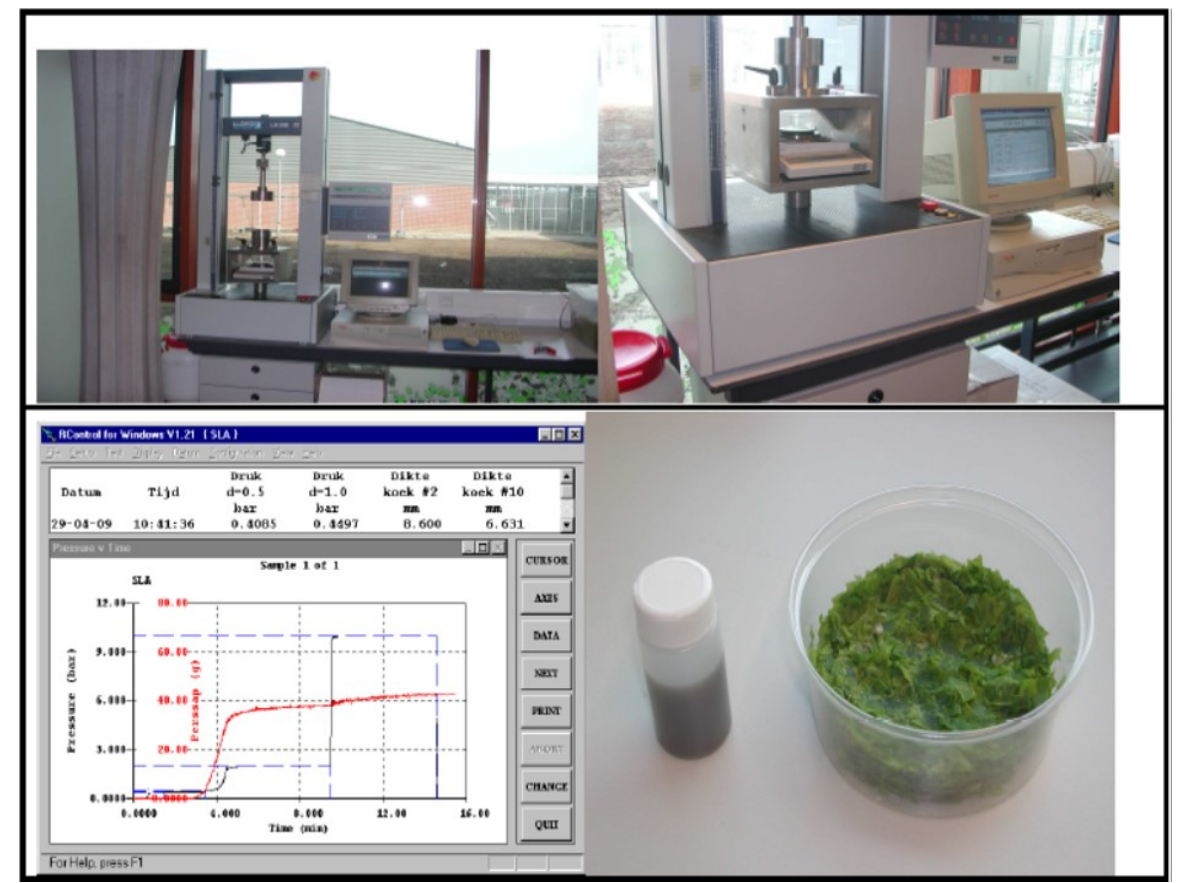

Figure 3. Example of a pressure experiment in the LR30K laboratory press with the seaweed Ulva lactuca.

seaweed, in comparison to $\approx 16 \times 10^{11}$ ton of terrestrial crops, grasses and forests (Buschmann et al., 2017). In addition, the present global natural seaweed production amounts 30 million tonnes of seaweed (FW) which corresponds to already $\approx 3 \%$ surface area of our "World Ocean" (Buschmann et al., 2017), and gives an annual global moisture content of $3.2 \times 10^{11}$ tonnes seaweed moisture.

In our calculations we used the pre-industrial oceanic $\mathrm{pH}$ environmental value of 8.25 (De'ath et al., 2009). Furthermore, we used in our calculations an average Dry Matter $(D M)$ percentage of $\approx 20 \%$ for seaweed green biomass (De'ath et al., 2009).

Methods to obtain data for Table 1: we can calculate for these two species the sequestering ability of seaweeds for $\mathrm{H}^{+}$ions based on the measured $\mathrm{pH}$ of seaweed moisture. The measured $\mathrm{pH}$ in the seaweed moisture of both seaweed species corresponds to 6.51 (see Table 1).

\section{Results}

Following our "calculation-model", the concentration of $\mathrm{H}^{+}$ions $10^{-6.51}=3.09 \times$ $10^{-7} \mathrm{~mol}$ per litre. The $\Delta \mathrm{pH}$ due to the $\mathrm{H}^{+}$ions sequestering photosynthetic mechanism and the pre-industrial oceanic $\mathrm{pH}$ environmental value of 8.25 corresponds to $\Delta \mathrm{pH}(8.25-6.51)=\Delta \mathrm{pH} 1.74$.

Next, we can calculate the amount of $\mathrm{H}^{+}$ions in ppm or mmol per liter: $\Delta \mathrm{pH}(8.25-6.51)=\Delta \mathrm{pH} .74 \geq \mathrm{pH}=-\log _{10} \mathrm{H}^{+} \Leftrightarrow$ [concentration] ocean $/$ [concentration] seaweed $=10^{\text {-delta } \mathrm{pH}}[\mathrm{mol} / \mathrm{l}] \approx 0.018$.

Based on Table 1 we can calculate for both "Sea lettuce" (Ulva lactuca) and "Asian Kelp" how much $\mathrm{H}^{+}$ions presently with the standing stock of seaweeds 
Table 1. Some characteristics for the at 10 bar mechanical pressed seaweed moisture for four seaweed species, Ulva lactuca, Caulerpa sertlatiodes and Caulerpa cf. brachypus and the brown seaweed Undaria pinnatifidia found at different locations like: salinity, nutrients like $\mathrm{N} \& \mathrm{P}$, and $\mathrm{pH}$ value and from this value calculated according to $10^{\mathrm{pH}}$ the amount of $\mathrm{H}^{+}$ions in (mol/l) was calculated (Raven et al., 2005). While humanity has to shift the $21^{\text {st }}$ century gradually towards a "green" bio-based economy in order to survive. With around 10,000 seaweed species in our oceans we can select the most appropriate species to sequester $\mathrm{H}^{+}$ions, heavy metals $(\mathrm{HM})$ and nutrients $(\mathrm{N} \& \mathrm{P})$. B.D.L. = Below detection limit.

\begin{tabular}{|c|c|c|c|c|c|c|c|c|}
\hline $\begin{array}{c}\text { Location } \\
\text { (origin) }\end{array}$ & $\begin{array}{l}\text { Seaweed } \\
\text { Species }\end{array}$ & $\begin{array}{c}\text { Salinity } \\
\text { Promille }\end{array}$ & $\mathrm{pH}$ & $\mathrm{H}^{+}$ & $\mathrm{N}-\mathrm{NH}_{4}{ }^{+}$ & $\begin{array}{c}\mathrm{N}-\left(\mathrm{NO}_{3} \&\right. \\
\left.\mathrm{NO}_{2}\right)\end{array}$ & N-tot & $\mathbf{P}$ \\
\hline & & $\%$ & & $\mathrm{~mol} / 1$ & $\mathrm{mg} / 1$ & $\mathrm{mg} / 1$ & $\mathrm{mg} / 1$ & $\mathrm{mg} / \mathrm{l}$ \\
\hline Ulva sp. & Ulva1 & 9.60 & 6.53 & 0.015 & 40.9 & 94.2 & 420.0 & 88.9 \\
\hline \multirow[t]{5}{*}{ Netherlands } & Ulva2 & 9.40 & 6.44 & 0.016 & 45.8 & 93.4 & 432.0 & 91.4 \\
\hline & Ulva3 & 9.40 & 6.55 & 0.015 & 42.7 & 90.6 & 360.0 & 83.1 \\
\hline & Ulva4 & 9.60 & 6.57 & 0.014 & 42.9 & 87.6 & 359.0 & 85.3 \\
\hline & Mean & $9.501(a)$ & 6.51 & 0.015 & 43.08 & 91.45 & 392.75 & 87.18 \\
\hline & Stdev & 0.115 & 0.055 & 0.001 & 2.027 & 2.99 & 38.71 & 3.694 \\
\hline Caul.sert. & CS1 & 19.10 & 4.81 & 0.081 & 4.81 & 37.3 & 362.0 & 45.0 \\
\hline \multirow[t]{5}{*}{ Indonesia } & CS2 & 19.30 & 4.20 & 0.150 & 4.61 & 38.2 & 344.0 & 45.0 \\
\hline & CS3 & 19.50 & 4.62 & 0.099 & 4.62 & 37.6 & 348.0 & 44.8 \\
\hline & CS4 & 19.30 & 4.62 & 0.099 & 4.71 & 37.5 & 351.0 & 45.20 \\
\hline & Mean & $19.30(b)$ & 4.563 & 0.107 & 4.69 & 37.65 & 351.25 & 45.00 \\
\hline & Stdev & 0.163 & 0.258 & 0.030 & 0.093 & 0.39 & 7.72 & 0.163 \\
\hline Caul.brach & C-b-1 & 20.50 & 4.51 & 0.110 & 14.40 & 369.0 & 922.0 & 91.40 \\
\hline \multirow[t]{5}{*}{ Cuba } & C-b-2 & 20.60 & 4.51 & 0.110 & 14.50 & 374.0 & 917.0 & 92.80 \\
\hline & C-b-3 & 20.70 & 4.50 & 0.111 & 14.60 & 377.0 & 920.0 & 92.50 \\
\hline & C-b-4 & 20.50 & 4.51 & 0.110 & 14.70 & 374.0 & 917.0 & 93.40 \\
\hline & Mean & $20.58(b)$ & 4.508 & 0.110 & 14.55 & 373.50 & 919.00 & 92.53 \\
\hline & Stdev & 0.096 & 0.005 & 0.001 & 0.129 & 3.32 & 2.45 & 0.838 \\
\hline Undaria & Und-1 & 9.60 & 6.53 & 0.015 & 14.60 & B.D.L. & 123.0 & 17.80 \\
\hline \multirow[t]{5}{*}{ Ireland } & Und-2 & 9.40 & 6.44 & 0.016 & 10.10 & B.D.L. & 96.6 & 12.60 \\
\hline & Und-3 & 9.40 & 6.50 & 0.015 & 8.27 & B.D.L. & 91.20 & 11.60 \\
\hline & Und-4 & 9.60 & 6.57 & 0.014 & 5.92 & B.D.L. & 83.10 & 10.60 \\
\hline & Mean & $9.50(a)$ & 6.510 & 0.015 & 9.72 & B.D.L. & 98.48 & 13.15 \\
\hline & Stdev & 0.115 & 0.055 & 0.001 & 3.674 & B.D.L. & 17.27 & 3.206 \\
\hline
\end{tabular}

are removed. So, the $\mathrm{H}^{+}$concentration of the seaweed moisture is 50 times higher than that of the ocean.

Based on a realistic model we continue the calculation the amount of hydrogen ions which needs to be removed from our "World Ocean".

In contrast, the present global natural seaweed production amounts 30 million 
tonnes of seaweed (FW) which corresponds to already $\approx 3 \%$ surface area of our "World Ocean" and gives an annual global moisture content of $3.2 \times 10^{11}$ tonnes seaweed moisture.

A standing crop of seaweeds on a global scale needs to be removed at once in order to eliminate $50 \times 3.2 \times 10^{11}=16 \times 10^{12}$ tonnes $\mathrm{H}^{+}$ions from our "World Ocean".

So, calculating for our "World Ocean": according to Equation (1) per mole $\mathrm{CO}_{2}$ two moles $\mathrm{H}^{+}$are produced so per annum $18 \mathrm{Gt}=1.8 \times 10^{16} \mathrm{~mol} \mathrm{H}^{+}=1.084$ $\times 10^{16} \mathrm{~mol} \mathrm{H}^{+}$ions per volume "World Ocean" needs to be sequestered in order to prevent a further oceanic $\mathrm{pH}$ decline.

Briefly, in our "World Ocean" we are aiming to remove around $1.8 \times 10^{16} \mathrm{~mol}$ of $\mathrm{H}^{+}$ions out of 1.37 billion cubic kilometers of saltwater $\geq 1800 \times 10^{14} / 50=36$ $\times 10^{14} \mathrm{~mol} \mathrm{H}^{+}$in 1.37 billion cubic kilometer of seaweed moisture.

This corresponds to $26.3 \times 10^{14} \mathrm{~mol} \mathrm{H}^{+}$in one billion cubic kilometer of seaweed moisture (giving: $1 \mathrm{~km}^{3}=1,000,000,000 \mathrm{~m}^{3}$ ), results in $1.0 \times 10^{18}$ cubic meter.

So, based on an average Dry Matter $(D M)$ percentage of $\approx 20 \%$ (see M \& M) $1.0 \times 10^{18} / 40=$ in an area covered with "Ulva lactuca bioreactors" of $250 \times 10^{16}$ ha seaweed production capacity per year needs to be produced and managed in order to eliminate at once all $\mathrm{H}^{+}$ions which cause OA in our "World Ocean" since the start of the "Industrial Revolution" $\approx 250$ years around AD 1870 .

\section{Discussion}

From our calculations we concluded an area covered with "Ulva lactuca bioreactors" (Figure 1) of $250 \times 10^{16}$ ha seaweed production capacity per year is needed in order to eliminate at once all $\mathrm{H}^{+}$ions which cause OA in our "World Ocean" since the start of the "Industrial Revolution" $\approx 250$ years around AD 1870 (Raven et al., 2005).

So, we can conclude this is an unfeasible case and we are aware our calculation may have been too optimistic to immediately aspire to neutralize our "World Ocean" by sequestering all $\mathrm{H}^{+}$ions at once and removing as waste in a suddenly arising amount of seaweed. It had only the purpose to give the reader a practical look at the sustainability of our "World Ocean" and about the enormous amounts of seaweed and hydrogen ions which are involved. By elucidating the complexity of the causes of OA and the current global state of our "World Ocean" we need to consider:

a) There are estimates that there are still some 10,000 unknown seaweed species in the ocean whose physiological \& biochemical properties are unknown with regard to photosynthesis (Hurd et al., 2014), so there might be seaweed species found that grow faster and sequester more $\mathrm{H}^{+}$-ions than Ulva lactuca which also appears from Table 1 where both Caulerpa sp. have a $\mathrm{pH}$ of the seaweed juice of $\approx 4.0$;

b) Nutrient enrichment negatively affects coral physiology including phytop- 
lankton blooms impose nutrient stress on coral reefs; seaweeds can trap these nutrients (Table 1) avoiding eutrophication (D'Angelo \& Wiedenmann, 2014);

c) $\mathrm{CO}_{2}$ sequestering in green biomass of seaweeds counteracts global- and indirectly oceanic warming (Duggins et al., 1989; Barker \& Ridgwell, 2012);

d) Heavy metals are toxic to corals-even at very low concentrations-and small amounts of heavy metal pollution even can kill corals. We demonstrated via ICP-techniques in seaweed moisture that seaweeds are champions in sequestering these toxic heavy metals in this way protecting coral reefs (van Ginneken \& de Vries, 2018);

e) In addition, it is not exactly known how much actual biomass of seaweeds are in the oceans. A 2008 report suggested that the Island of Orkney (UK) has a Kelp forest of one million tons covering 22,000 hectares along $800 \mathrm{~km}$ of coastline (Christiansen, 2008). This equates to $44.5 \mathrm{t}$ of Kelp per hectare. It further suggested that there are approximately 100,000 hectares of Kelp forests in UK waters which could be commercially harvested. Kelp (or Laminaria) is typically found at depths of 8 to $30 \mathrm{~m}$ in the north Atlantic. Kelps are considered optimal for bioconversion to energy (Milledge et al., 2014). In a study with stable carbon isotopes, (Duggins et al., 1989) demonstrated that Kelp seaweed communities are important $\mathrm{CO}_{2}$ sinks and thus help to prevent global warming.

It appears from all these examples that seaweeds and coral reefs work on the two extremes of an ecosystem. This may also be apparent from a natural coral ecosystem that is naturally volcanic erupted and subsequently overgrown by seaweeds (Enochs et al., 2015).

There are many examples mentioned in this manuscript that indicate that a diligent search is being made for solutions to save our global coral reefs. Perhaps not one direct global solution should be sought, but the sum of all those individual components which can work synergistically is greater than the total sum of the individual parts.

That there is still hope for the recovery of our coral reefs is evident from all these individual initiatives to combat OA. People are increasingly thinking and operating more greener and ecosystems are more protected.

This recovery in the practice of our coral reefs has been proven based on the results from the experiment of (Albright et al., 2016) where it has been demonstrated that if OA is stopped, coral reef calcification is accelerated.

Furthermore, seaweed plantations can act as a natural oceanic sink for anthropogenic $\mathrm{CO}_{2}$ to combat "Global Warming" (Duggins et al., 1989; Barker \& Ridgwell, 2012) through giant seaweed farms across the world's oceans (Figure 4), which would meet the Kyoto Protocol (Laffoley \& Grimsditch, 2009).

It seems like a daunting or even an impossible task to build ocean seaweed plantations for the "World Ocean" to prevent OA. But we must remind that since the beginning of the "Industrial Revolution" around AD 1870 over an extremely long period of $\approx 250$ years these OA processes are under way. The wry thing about this story is that humanity, through the "laissez-faire" policy of 


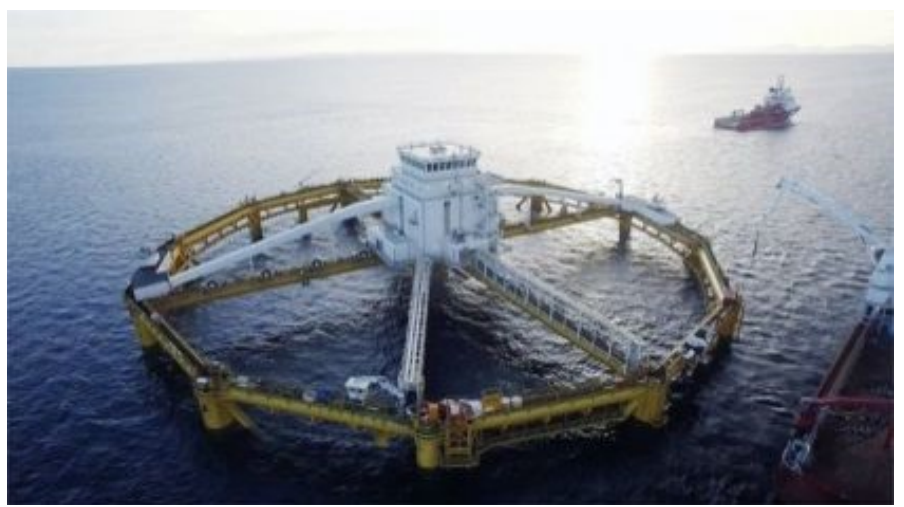

Figure 4. Futuristic giant seaweed farm in our "World Ocean".

mainly the baby-tree generation of the previous century, now has to find a solution in barely 30 years (van Ginneken \& de Vries, 2015).

This will also require huge economic investments estimated at around 8 trillion US\$ (Bishop \& Hill, 2014).

But two comments have to be made:

a) The shift towards a bio-based economy does not take place on land but in the eutrophic oceans where the seaweed industry can grow into a truly green biomass creating industry.

b) We should not invest money in rehabilitation projects of dying reefs but tackle the problem at the base. That is a recently observed biological mechanism or $\mathrm{H}^{+}$sequestering by growing seaweeds.

A major advantage of this crop is that it is itself not affected in its growth by OA but is rather stimulated as indicated by recent studies of (Britton et al., 2016). In assessing the environmental sustainability and combat ocean acidification there is scope to consider the role of seaweed plantations in removing $\mathrm{H}^{+}$ ions from our "World Ocean". In this way the presently massive and collective "bleaching" of coral reefs can be prevented (Figure 5).

\section{Conclusion \& Perspectives}

This research manuscript gives a reflection of a problem which accumulated in our World Ocean over a time-frame of 250 years but clearly reflects no "natural" solutions are presently available to neutralize our World Ocean at once. But the clear description of this problem in this manuscript itself could be very useful for future studies and techniques for the International Scientific Community to handle this problem and find a new innovative technique/solution to neutralize our "World Ocean".

The requested area covered with "Ulva lactuca bioreactors" of $250 \times 10^{16}$ ha seaweed production capacity per year is needed in order to eliminate at once all $\mathrm{H}^{+}$ions which cause OA in our "World Ocean" is a daunting task. Perhaps finding a solution to the OA problem in this proposed natural way via seaweeds can be accelerated by using improved seaweed species with a larger absorption spectrum of $\mathrm{H}^{+}$ions. Another solution could be by positioning these 


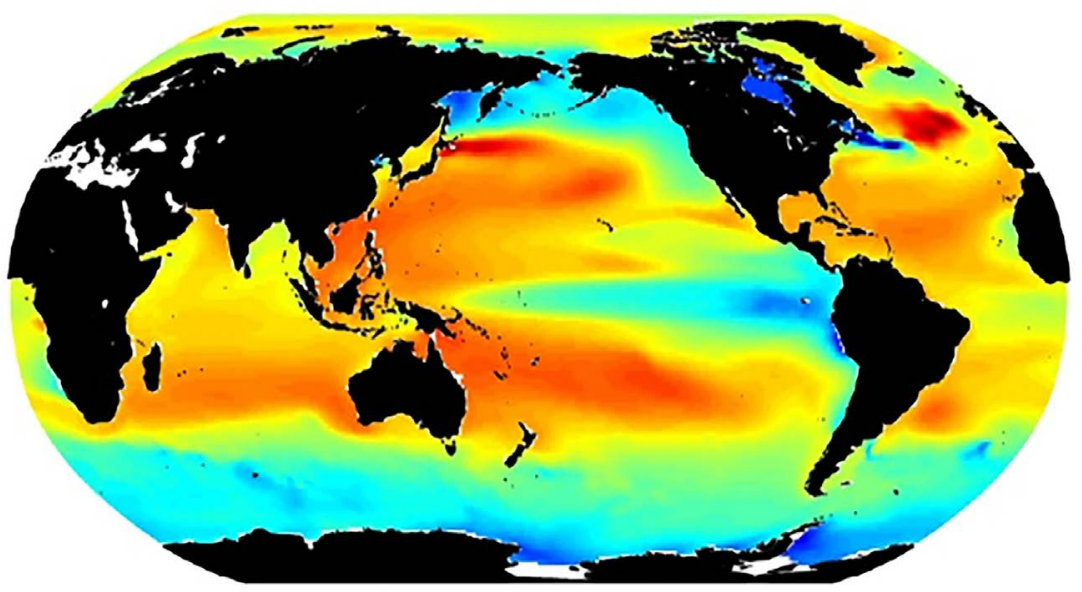

Change in aragonite saturation at the ocean surface $\left(\Omega_{\mathrm{ar}}\right)$ :

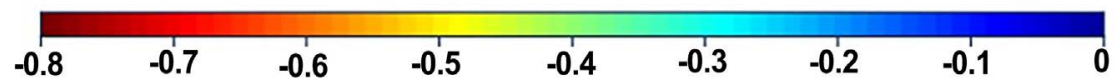

Figure 5. Changes in Aragonite Saturation of the World's Oceans, 1880-2012. The underlying architecture of the reef is a biogenic carbonate structure responsible for years of active biomineralization by calcifying organisms including corals and algea ${ }^{2}$. Ocean acidification is a chronic threat to coral reefs by reducing the saturation state of the aragonite mineral, or which coral skeletons are concentrated and reducing the concentration of carbonate ions needed to maintain the carbonate reef. Reduced calcification, combined with increased bioerosion and dissolution, can bring reefs into a state of net loss this century.For more information, visit US EPA's "Climate Change Indicators in the United States” at www.epa.gov/climatechange/indicators (Source modified: Feeley et al., 2009).

giant seaweed farms (Figure 4) at our "World Ocean", contrary to the earlier proposed land-based "Ulva bioreactor" (Figure 1).

Presently, to preserve our current coral reefs, the OA process needs to be halted. In doing so, we will have to deal temporarily with a range of the under a) up to and including e) mentioned variables (see Discussion) which would justify the protection and rehabilitation of our coral reefs-hopefully supported by synergy-which would strengthen the net effect.

Finally, the power and originality of this manuscript lies in the original, robust and reliable calculations performed by "Biometris"-Institute, Wageningen University, Netherlands (see acknowledgments), by which the problem of OA since the start of the Industrial Revolution starting around 250 years ago clearly has been elucidated for the International Scientific Community.

\section{Acknowledgements}

Dr. GA (Guus) ten Broeke and Prof. Dr. Jaap (J) Molenaar, Department of Plant Sciences, Biometris, Wageningen University, Netherlands, are kindly acknowledged for performing the calculations in this manuscript. The management team of Blue Green Technologies, Jaap van Meerveld, Albert Frans Welmers, Jan Rochard and Hans Lammers is kindly acknowledged for supportive action and kind support. 


\section{Conflicts of Interest}

The author declares no conflicts of interest regarding the publication of this paper.

\section{References}

Albright, R., Caldeira, L., Hosfelt, J., Kwiatkowski, L., Maclaren, J. K., Caldeira, K. et al. (2016). Reversal of Ocean Acidification Enhances Net Coral Reef Calcification. Nature, 531, 362-365. https://doi.org/10.1038/nature17155

Barker, S., \& Ridgwell, A. (2012). Ocean Acidification. Nature Education Knowledge, 3, 21. https://www.nature.com/scitable/knowledge/library/ocean-acidification-25822734

Battle, M., Bender, M. L., Tans, P. P., White, J. W., Ellis, J. T., Conway, T., \& Francey, R. J. (2000). Global Carbon Sinks and Their Variability Inferred from Atmospheric $\mathrm{O}_{2}$ and $\delta^{13}$ C. Science, 287, 2467-2470. https://doi.org/10.1126/science.287.5462.2467

Bishop, J., \& Hill, Ch. (2014). Global Biodiversity Finance; the Case for International Payments for Ecosystem Services; in Association with IUCN and UNEP, IUCN 2014.

Britton, D., Cornwall, C. E., Revill, A. T., Hurd, C. L., \& Johnson, C. R. (2016). Ocean Acidification Reverses the Positive Effects of Seawater $\mathrm{pH}$ Fluctuations on Growth and Photosynthesis of the Habitat-Forming Kelp, Ecklonia radiata. Scientific Reports, 6, Article No. 26036. https://doi.org/10.1038/srep26036

Bruhn, A., Dahl, J., Nielsen, H. B., Nikolaisen, L., Rasmussen, M. B., Markager, S., Olesen, B., Arias, C., \& Jensen, P. D. (2011). Bioenergy Potential of Ulva lactuca: Biomass Yield, Methane Production and Combustion. Bioresource Technology, 102, 2595-2604. https://doi.org/10.1016/j.biortech.2010.10.010

Buschmann, A. H., Camus, C., Infante, J., Neori, A., Israel, Á., Hernández-González, M. C., Pereda, S. V., Gomez-Pinchetti, J. L., Golberg, A., Tadmor-Shalev, N., \& Critchley, A. T. (2017). Seaweed Production: Overview of the Global State of Exploitation, Farming and Emerging Research Activity. European Journal of Phycology, 52, 391-406. https://doi.org/10.1080/09670262.2017.1365175

Caldeira, K., \& Wickett, M. E. (2003). Anthropogenic Carbon and Ocean pH. Nature, 425, 365-365. https://doi.org/10.1038/425365a

Christiansen, R. C. (2008). British Report: Use Kelp to Produce Energy. http://www.biomassmagazine.com/articles/2166/British-report-use-kelp-to-produce-e nergy

D’Angelo, C., \& Wiedenmann, J. (2014). Impact of Nutrient Enrichment on Coral Reef: A New Perspectives and Implications for Coastal Management and Reef Survival. Current Opinion in Environmental Sustainability, 7, 82-93. https://doi.org/10.1016/j.cosust.2013.11.029

De'ath, G., Lough, J. M., \& Fabricius, K. E. (2009). Declining Coral Calcification on the Great Barrier Reef. Science, 323, 116-119. https://doi.org/10.1126/science.1165283

Doney, S. C., Fabry, V. J., Feely, R. A., \& Kleypas, J. A. (2009). Ocean Acidification: The Other $\mathrm{CO}_{2}$ Problem. Annual Review of Marine Science, 1, 169-192. https://doi.org/10.1146/annurev.marine.010908.163834

Duggins, D. O., Simenstad, C. A., \& Estes, J. A. (1989). Magnification of Secondary Production by Kelp Detritus in Coastal Marine Ecosystems. Science, 245, 170-173. https://doi.org/10.1126/science.245.4914.170

Enochs, I. C., Manzello, D. P., Doham, E. M., Kolodziej, G., Okano, R., Johnston, L., Price, N. N. et al. (2015). Shift from Coral to Macroalgae Dominance on a Volcanically Acidified Reef. Nature Climate Change, 5, 1083-1088. 
https://doi.org/10.1038/nclimate2758

Feeley, R. A., Doney, F. S., \& Cooley, S. R. (2009). Ocean Acidification: Present Conditions and Future Changes in a High- $\mathrm{CO}_{2}$ World. Oceanography, 22, 36-47. https://doi.org/10.5670/oceanog.2009.95

Hall-Spencer, J. M., Rodolfo-Metalpa, R., Martin, S., Ransome, E., Fine, M., Turner, S. M., Rowley, S. J., Tedesco, D., \& Buia, M. C. (2008). Volcanic Carbon Dioxide Vents Show Ecosystem Effects of Ocean Acidification. Nature, 454, 96-99. https://doi.org/10.1038/nature07051

Hurd, C. L., Harrison, P. J., Bischof, K., \& Lobban, C. S. (2014). Seaweed Ecology and Physiology (2nd ed., 551 p.). Cambridge: Cambridge University Press. https://doi.org/10.1017/CBO9781139192637

Laffoley, D. A., \& Grimsditch, G. (2009). The Management of Natural Coastal Carbon Sinks (53 p.). Gland: IUCN.

Milledge, J. J., Smith, B., Dyer, P. W., \& Harvey, P. (2014). Macroalgae-Derived Biofuel: A Review of Methods of Energy Extraction from Seaweed Biomass. Energies, 7, 71947222. https://doi.org/10.3390/en7117194

Mora, C., Wei, C. L., Rollo, A., Amaro, T., Baco, A. R. et al. (2013). Biotic and Human Vulnerability to Projected Changes in Ocean Biogeochemistry over the 21st Century. PLoS Biology, 11, e1001682. https://doi.org/10.1371/journal.pbio.1001682

Normille, D. (2010). Hard Summer for Corals Kindles Fears for Survival of Reefs. Science, 329, 1001. https://doi.org/10.1126/science.329.5995.1001

Oreskens, N. (2004). The Scientific Consensus on Global Warming. Science, 306, 1686. https://doi.org/10.1126/science.1103618

Orr, J. C., Fabry, V. J., Amount, O., Yool, A. et al. (2005). Anthropogenic Ocean Acidification over the Twenty-First Century and Its Impact on Calcifying Organisms. Nature, 479, 681-686. https://doi.org/10.1038/nature04095

Pennisi, E. (2009). Coral Reefs. Calcification Rates Drops in Australian Reefs. Science, 323, 27. https://doi.org/10.1126/science.323.5910.27

Raven, J., Caldeira, K., Elderfield, H., Hoegh-Guldberg, O., Liss, P. S., Riebesell, U., Sheperd, J., Turley, C., \& Watson, A. (2005). Ocean Acidification Due to Increasing Atmospheric Carbon Dioxide (57 p.). Royal Society Policy Document. https://ueaeprints.uea.ac.uk/id/eprint/32712

van Ginneken, V. (2017). The Photosynthetic System of the Seaweeds: The Seaweed Paradox. Asian Journal of Science and Technology, 8, 6567-6571.

van Ginneken, V. (2018). Some Mechanisms Seaweeds Employ to Cope with Salinity Stress in the Harsh Euhaline Oceanic Environment. American Journal Plant Sciences, 9, 1191-1211. https://doi.org/10.4236/ajps.2018.96089

van Ginneken, V., \& de Vries, E. (2015). Towards a Seaweed Based Economy. Journal of Fisheries Sciences, 9, 85-88.

van Ginneken, V., \& de Vries, E. (2016). Towards a Seaweed Based Economy: The Global Ten Billion People Issue at the Midst of the 21st Century. Journal of Fisheries Sciences, 10, 1-11.

van Ginneken, V., \& de Vries, E. (2018). Seaweeds as Biomonitoring System for Heavy Metal (HM) Accumulation and Contamination of Our Oceans. American Journal of Plant Sciences, 9, 1514-1530. https://doi.org/10.4236/ajps.2018.97111

van Ginneken, V., de Vries, E., \& Wijgerde, T. (2016). A Suggested "Seaweed-Plantation Model" to Tackle the Looming Phosphorus Crises in the 21st Century at the Rhine/ North Sea System. Journal of Fisheries Sciences, 9, 105-114. 